\title{
Dynamic Analysis for Measuring the Impact of Remittance Inflows on Inflation: Evidence From Georgia
}

\author{
Azer Dilanchiev $^{1}$, Aligul Aghayev ${ }^{2}$, Md. Hasanur Rahman ${ }^{3}$, Jannatul Ferdaus ${ }^{3} \&$ Araz Baghirli $^{2}$ \\ ${ }^{1}$ Department of Economics, International Black Sea University, Tbilisi, Georgia \\ ${ }^{2}$ Azerbaijan State University of Economics, Azerbaijan \\ ${ }^{3}$ Department of Economics, Comilla University, Cumilla, Bangladesh \\ Correspondence: Md. Hasanur Rahman, Department of Economics, Comilla University, Cumilla, Bangladesh. \\ E-mail: hasanur.cou@gmail.com
}

Received: November 20, 2020

Accepted: December 24, $2020 \quad$ Online Published: January 10, 2021

doi:10.5430/ijfr.v12n1p339

URL: https://doi.org/10.5430/ijfr.v12n1p339

\begin{abstract}
Remittance plays a critical role for small economies like Georgia as an unusual means of financing. In policy-making decisions, an understanding of the essence of the relationship between the amount of money exchanged and inflation is important. The paper studies the impact of remittance inflows, using quarterly data spanning a period (2000-2018), on the inflation rate in Georgia. The paper revealed that all independent variables have an effect on the long-run inflation rate; long-run inflation is positively associated with the leading explanatory variable remittance, and no relation is found in the short-run between remittance and inflation. The paper found that inflation's adjustment level to its equilibrium is $12 \%$ annually.
\end{abstract}

Keywords: remittances, inflation, co-integration, VECM

\section{Introduction}

Remittances are one of the biggest capital inflows for developing countries, which are the primary beneficiaries of a significant portion of remittances. Remittance inflows have a significant influence on financial and economic stability and poverty reduction in developing countries (Acosta et al., 2008; Gupta et al., 2009; Imai et al., 2014). Remittance inflows play a notable role in the recipient country's economic growth and development (Giuliano and Ruiz-Arranz, 2009; Rao and Hassan, 2011; Nyamongo et al., 2012). In total, $\$ 528$ billion was received in 2018 by developing nations, which is 76.6 percent of all remittances made in 2018 (World Bank, 2018). While the positive effects of remittances on the economy are obvious, they have some negative effects and are also responsible for the occurrence of macroeconomic instability. Remittance is indirectly connected to inflation, but this relationship is technically strong. Remittances may contribute to inflation, and in the long term the effects can become more evident (Narayan et al., 2011).

Georgia is a small country with large migrant outflows and remittance inflows. Georgia is still known as a transitional economy, driven by its former affiliation to the Soviet Union. As a factor that keeps the exchange rate steady, as an alternate source of funding and as an important source of income for domestic households, remittances are crucial to the Georgian economy. It plays a significant part in Georgia's economic life (Abdaladze, 2012). In 2018, compared to 2017, the volume of remittances in Georgia increased by 14 percent and amounted to $\$ 1.57$ billion (The National Bank of Georgia, 2018). In March 2020, Georgia received a total of $\$ 125.9$ million from abroad, according to the National Bank of Georgia, which is 9 per cent less than the amount received in March 2019 (Agenda.ge, 2020). Since 2016, remittances have increased in Georgia, as reported by the World Bank, and in recent years they have surpassed $10 \%$ of the gross domestic product, which represents a heavy inflow of remittances from the European Union and Israel, and this inflow has recently decreased due to the COVID-19 pandemic (Agenda.ge, 2020). The International Monetary Fund (IMF) has predicted that remittance flows are projected to decline by 15 percent. 


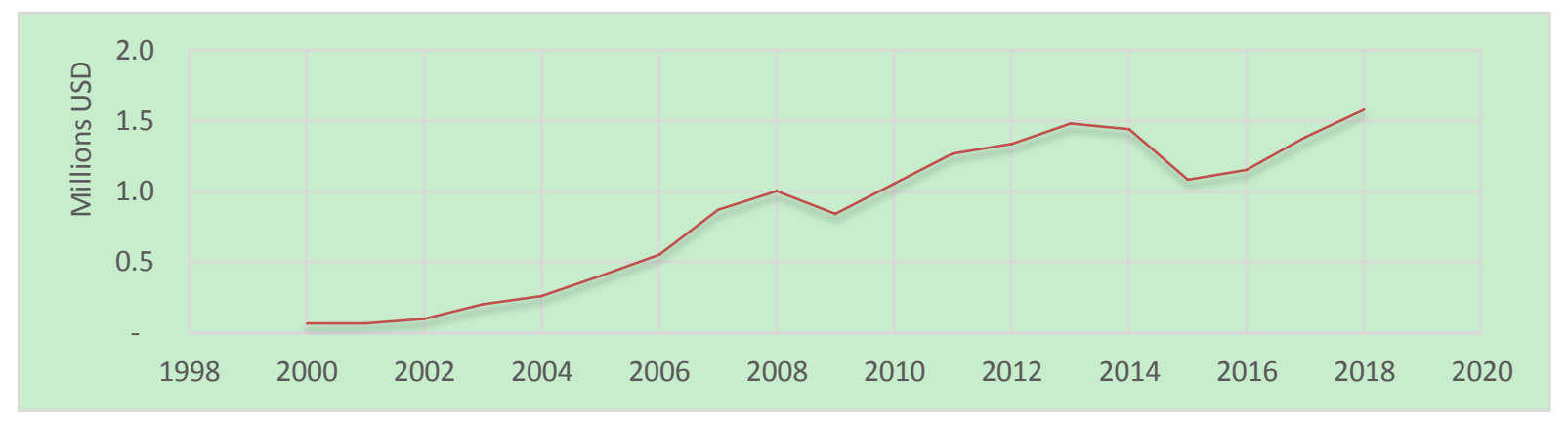

Figure 1. Remittances to Georgia in 2000-2018

Source: The National bank of Georgia

The economically active movement of the population leaving Georgia and the visa-free regime with the EU is indirectly leading to the rise in remittance inflows. Since a large number of Georgians have migrated internationally and most of them live in the Russian Federation, Ukraine, the United States, Greece, Italy , Spain, Turkey, remittances have a direct effect on Georgia 's economy, such as national reserves, as well as providing income for nearly one in ten individuals across the world. According to information from the National Bank of Georgia, Russia, Italy and Greece were the three main remittance senders in Georgia in March 2020 and received \$25.39 million, \$17.31 million and \$16.24 million respectively from Russia, Italy and Greece.

Russia remains the most lucrative and most common place of employment for Georgians abroad, based on official data. Out of a total of $\$ 1.57$ billion, $\$ 457.5$ million was moved in 2018 from Russia to Georgia (28.5\%), a rise of $0.5 \%$ compared to 2017. After the visa-free regime agreement with the EU on 28 March 2017, remittances from the EU began to expand. According to data from 2018, Italy 's primary growth of 33.8 percent-\$191.1 million (12 percent of the total) and 16 percent-was delivered by Greece, the amount of money transfers from which reached $\$ 170.2$ million (10 percent of the total).

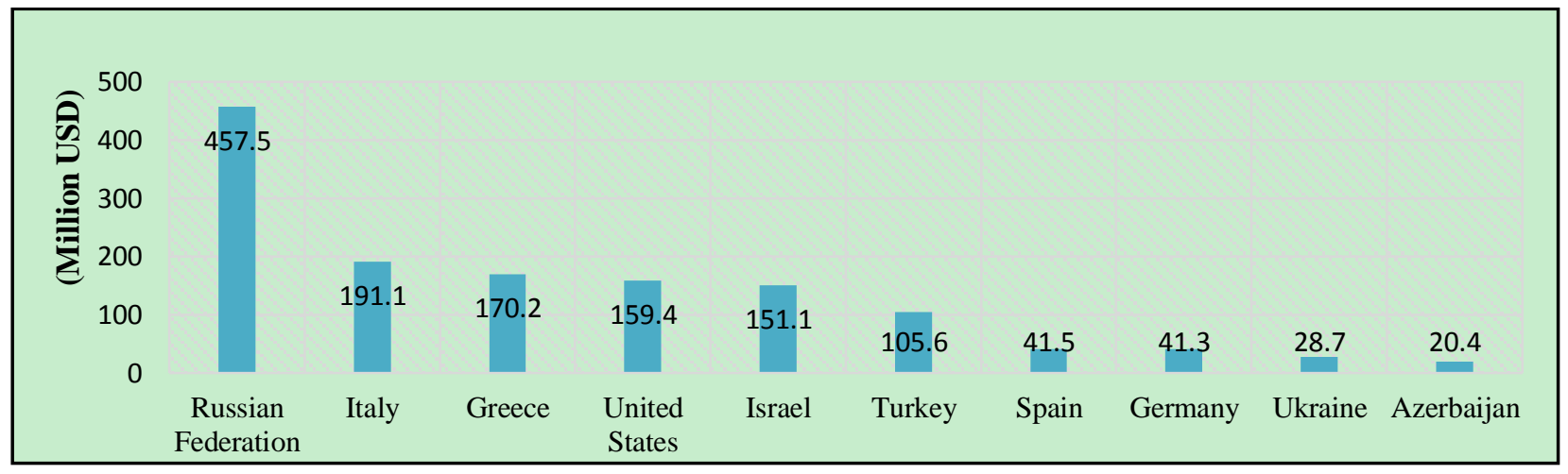

Figure 2. Top ten (countries) remittance earning sources of Georgia

Source: NBG, 2019

The annual inflation rate in Georgia was 4.90 percent in 2019, falling to 3.8 percent in September 2020, which is the lowest inflation rate since March 2019. Georgia's inflation rate is estimated at 6 percent in 2020 by the Asian Development Bank (ADB) and is forecast to decline to 4.5 percent in 2021 (ADO 2020 Update). Throughout the early 2000s, Georgia had a low inflation rate and the average annual inflation rate was 13.7 percent between 1995-2019. 


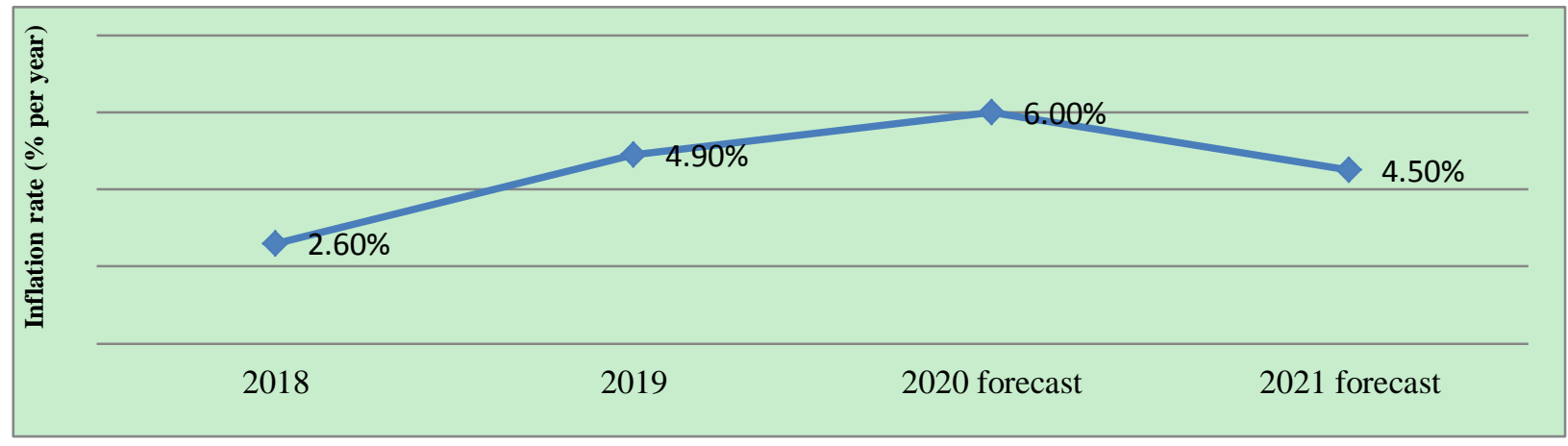

Figure 3. Inflation rate (\% per year) of Georgia

Source: Asian Development Outlook (ADO) 2020

Remittance inflow represents the capital which, for a small developing country like Georgia, retains financial sustainability. Based on the growing effect and magnitude of remittances in developing countries and the fact that they have a negative impact on price stability, it has become increasingly important to examine the impact of remittances on inflation. There is also no way to ignore the adverse effect of remittance on the receiving country in the form of Dutch disease and moral hazard issue (Nisar and Tufail, 2013). For Georgia, where the importance of remittances can not be ignored, the issue becomes even more important. By taking quarterly data from the National Bank of Georgia from 2000 to 2018 and applying the Vector Error Correction Model (VECM) to analyze the relationship between the variables, the purpose of the work is to explore how inflation will be influenced by remittance inflows in Georgia.

The remainder of this paper is structured as follows. Section 2 provides a review of the relevant literature. The econometric models and the dataset used in this paper are explained in Section 3. Section 4 discusses the empirical findings and Section 5 concludes.

\section{Literature Review}

A good number of researches have been conducted to assess the macroeconomic impacts of remittances and to determine whether inflation is affected by remittances positively or negatively. But most of the remittance-inflation-nexus studies display contradictory results. Some authors have explored that remittances contribute positively to the promotion of recipient countries' economic growth and development, while some authors have revealed that remittances cause inflation in recipient countries. Some previous literature relevant to this problem is listed in this section. Ohlin (1929) and Keynes (1929) were the writers who first initiated the debate on the effect of remittance inflows on the economies of the receiving countries. Later, the subject was referred to as the Transfer Issue.The subject is very real and attracts the attention of many authors who focus on various aspects of the remittance effect, such as fixed and floating exchange rate regimes in developed economies (Bourdet and Falck, 2006; Lartey et al., 2012). The papers on the inflation effects of remittances are limited or include numerous and contradictory results. The general characteristics of remittances are that they are used either for investment purposes or for consumption, in addition to acting as an alternate source of finance. The primary influence of remittance on aggregate demand (AD), which can cause inflation, is pointed out by Adelman and Taylor (1996). The primary influence on the $\mathrm{AD}$ of remittances is that household spending rises, resulting in a rise in remittances that can lead to inflation. Remittances boost consumption, followed by an increase in aggregate demand through monetary expansion, leading to inflation-pulling demand. Mughal (2012) also claimed remittance as an influencer of demand-pull inflation. Single country models that apply time series are also common in contemporary literature that focuses primarily on remittance and inflation relationships, along with panel data models that deal with multiple countries and variables. The Johansen co-integration test to calculate long-run co-integration and vector models is one of the common techniques used by authors to evaluate cases in a single country. The El Salvador study found that remittances raise household prices and have a positive effect on interest rates. At the same time, it limits the supply of capital and affects industry adversely (Cáceres and Saca, 2006). The paper Puja (2013) analyzed the effect of remittances on an aggregate scale, revealing that the concentration of remittances on total consumption would lead to a decline in the economy and have a negative impact on export quantities. Roy and Rahman's (2014) Vector Error Correction Model (VECM) findings have found that remittance not only raises inflation but also positively relates to 
food prices and increases food inflation at the same time.

Moreover, Mumunt and Quaidoo (2016), analyzing the impact of money transferred on prices in Ghana using the ARDL boundary test method by applying 34-year annual time series results, revealed no short-term relationship between remittance and inflation and a significant positive long-term relationship. By applying GMM data, Faisal et al. (2017) analyzed the macroeconomic determinants of remittance in Pakistan and revealed a major influence of economic parameters over remittance. Johanna et al. (2017) studied the reaction of remittances sent to the revolution by Tunisian emigrants; they found that remittances would minimize the negative impact of a revolution in Tunisia's political and economic turmoil. Rivera and Tullao Jr (2020) carried out research using VAR methodology to investigate the correlation between remittances and inflation for the Philippines during the study period from January 2000 to October 2019. The results of the study's empirical findings show that remittances are not inherently inflationary. For the period 2001-2007, Rashid and Husain (2010) analyzed capital inflows in Pakistan and discovered the long-term relationship between capital and inflation by applying co-integration tests. Another study conducted by Nisar and Tufail (2013) for Pakistan established that remittances had a positive effect on inflation through the use of the Vector Error Correction technique over the period 1970-2010.

The nexus between remittances and inflation in Pakistan over the period 1980-2012 was also investigated by Iqbal et al. (2013) and the results obtained from the VECM evidences also showed that remittances have a major positive inflation effect. For the period 1995-2009, another analysis by Mandelman (2012) used the Dynamic Stochastic General Equilibrium (DSGE) model on Philippine results. The results of his study show that inflation often increases if remittance increases. For 38-year annual data from 1972 to 2010, Khan and Islam (2013) used the vector autoregressive (VAR) method, analyzing the impact of the amount of money transferred on the overall price level in Bangladesh. They found that money transferred had a positive effect on the inflation rate in the long run; however, no significant association was found between analyzed variables in the model in the short term. Balderas and Hiranya (2005) examined that, between 1988-2005, remittances had a major positive effect on inflation in Mexico.

Nevertheless, Katseli and Glytsos (1986) showed in an analysis of Greece that the amount of money transferred was inversely related to the overall price level. Nath and Silva (2012) used VAR to research the effect of remittance inflows on recipient economies' price distribution, including a distinct relative price development using monthly data in Mexico for 272 consumer products. The research finding showed that if remittances rise, the relative prices of certain non-tradable commodities such as houses rise steadily, whereas the prices of some long-lasting commodities such as equipment appear to fall. Merima (2011) found that a large proportion of remittance inflows in transition economies are aimed at investment projects rather than consumption.

Arellano and Bond (1991) discovered a major effect on inflation from money transfers. They used dynamic analysis of panel data from various developed countries. They concluded that the impact of the amount of money transferred on inflation in the long term is more pronounced in developed economies. Positive relations between remittances and inflation were also found by Lopez et al. (2007) and Narayan et al. (2011). In the case of 32 Asian and Pacific developing countries covering the 1985-2013 study period, Tung et al. (2015) examined the effect of remittance inflows on inflation. The study discovered that remittance inflows dramatically increased inflation during the research period by applying the Ordinary Least Squares (OLS), Two-Stage Least Squares (2-SLS), Panel Generalized System of Moments (PGMM) methods. While analyzing the influence of remittance on inflation for seven Latin American countries, taking into account both annual and quarterly data from 1980:1 to 2006:4 with different exchange rate regimes, Ball et al. (2013) found that remittance flow causes deflation in economies with floating exchange rate regimes and positively influences the exchange rate. Whereas in fixed exchange economies, remittance causes the overall price level to rise in the short term through the channel of accumulation of liquidity.

Based on the above analysis of literature, it is possible to say that there is still a scientific gap and space for analyzes the effect of remittances over inflation in Georgia as a country with floating exchange rate regime and steady remittance growth.

\section{Data and Methodology}

In this paper, by considering other macroeconomic variables such as exchange rate and broad money (M2), we estimate the relationship between remittance inflows and inflation. The exchange rate has been used as an efficient exchange rate in two separate ways, and as an average exchange rate, which explains the exchange rate trend in the Georgian economy. The study of the time series took into account quarterly data from 2000-2018. The vital data sources for this analysis are International Financial Statistics (IFS) and the National Bank of Georgia (NBG). We have adjusted all variables in the common logarithm with the ultimate aim of the investigation as it restricts the variances in the arrangement of knowledge (Tiwari and Mutascu 2010). Above all, to consider the proposal for 
coordination of the system. To understand the fixed stage, the unit root test of Dickey and Fuller (1981) was used. The level of cointegration among the variables was measured by Johansen and Juselus (1990) cointegration test. The method has been widely adopted by the scientific community to study the cointegration and the long-run relation between variables. The long-run equation is illustrated below (1).

$$
\ln C P I_{t}=\alpha_{0}+\alpha_{1} \ln R M_{t}+\alpha_{2} \ln M 2_{t}+\alpha_{3} \ln R E E R+\alpha_{4} \ln A E X+\mu_{t}
$$

Where,

$\operatorname{lnCPI}=$ Inflation rate

lnREM= Remittance inflow

Monetary Variables based on Balderas (2009) and Khan and Islam (2013) analysis:

$\operatorname{lnREER}=$ represents the logarithm of the effective exchange rate

$\ln \mathrm{M} 2=$ represents the broad money

$\ln \mathrm{AEX}=$ represents the exchange rate in average

$\mu=$ represents the error term

$\mathrm{t}=$ represents time dimension

Following the cointegration result (VECM) method can be easily adapted to conduct a wide range of analysis on the short and long term dynamics of factors of the model

Error correction term can be described in cointegration model through an equation such as the following:

$$
\Delta y_{t}=\alpha_{0}+\sum_{i=1}^{n} \beta_{i} \Delta v_{t-1} \sum_{i=0}^{n} \delta_{i} \Delta k_{t-1}+\theta z_{t-1}+\mu_{t}
$$

In the model, (z)-represents - error correction term (ECT), and defined as:

$$
E C T_{t-1}=v_{t-1}-\alpha_{0}-\beta_{1} k_{t-1}
$$

The ECT illustrates the adjustment speed of the variable to the long-term equilibrium and impact of the short-run dynamics on the explanatory variable, inflation. It measures the adjustment level at which the predicted variable (LnCPI) turns to equilibrium after a change in the explanatory variable (LnRM).

\section{Econometric Results Analysis}

Before the estimation of cointegration, as stated in the methodology section, the order of integration of the respective variables for the methodology should not be verified (Dickey and Fuller, 1981). However, for two reasons, this study performed the unit root: first to ensure that variables exceeded the order of integration I(1) and then to explain the appropriateness of applying the approach to VECM rather than the traditional approaches to cointegration.

Table 1 shows that the logarithmic form of CPI ((inflation) proxies by consumer price index) was stationary at I(1). However, the RM was found to non-stationary at $\mathrm{I}(0)$, but it was stationary after taking the first difference. The ADF test also revealed that the $\mathrm{M}_{2}$ was non-stationary at $\mathrm{I}(0)$ but stationary at $\mathrm{I}(1)$. Similarly, the exchange rate (average) and the effective exchange rate were stationary at I(1). Therefore, the presence of such I(1) orders of integration, as reported in the ADF test, endorsed the application of the VECM approach instead of conventional econometric approaches. Based on the results of the test that indicates a significance level of all variables with 1 percent and the only remittance with a 5 percent significance level, we can reject the $\mathrm{H}_{0}$ hypothesis. In the analysis schwarz information criterion (SC) lag order 1 was used as an optimal lag length for the VAR specification in the model and the result has been presented in Table 2 .

Table 3 illustrates the findings of the Johansen co-integration test. The Johansen cointegration test was chosen as an ideal technique to calculate the degree of cointegration, based on the Augmented Dickey-Fuller ( ADF) unit root test results of four variables that found stationarity in all variables in the first level. Trace and Max-Eigen's test results showed that at least one co-integration was important in the model and dismissed the $\mathrm{H} 0$ test hypothesis, suggesting the existence of co-integration and long-term relationships between the model variables. 
Table 1. The Augmented Dickey-Fuller Test for five variables

\begin{tabular}{|c|c|c|c|c|c|}
\hline \multirow{2}{*}{ Variables } & \multicolumn{3}{|c|}{ Critical values } & \multirow{2}{*}{ ADF statistics } & \multirow{2}{*}{ Decision } \\
\hline & $1 \%$ & $5 \%$ & $10 \%$ & & \\
\hline $\ln C P I$ & -3.522887 & -2.901779 & -2.588280 & $-8.873223 * * *$ & Reject H0 \\
\hline $\operatorname{lnRM}$ & 3.525618 & -2.902953 & -2.588902 & $-3.157255^{* *}$ & Reject H0 \\
\hline $\ln \mathrm{M} 2$ & -3.521579 & -2.901217 & -2.587981 & $-5.481625^{* * *}$ & Reject H0 \\
\hline lnREER & -3.522887 & -2.901779 & -2.588280 & $-6.585376^{* * *} *$ & Reject H0 \\
\hline $\ln \mathrm{AEX}$ & -3.522887 & -2.901779 & -2.588280 & $-6.301532 * * *$ & Reject H0 \\
\hline
\end{tabular}

Notes: $* * *, * *, *$, indicates the significance at $1,5,10$ percent.

Table 2. Selection criteria VAR

\begin{tabular}{cl}
\hline Lag & SC \\
\hline 0 & -5.981960 \\
\hline 1 & $-17.12251^{*}$ \\
\hline 2 & -16.92416 \\
\hline 3 & -16.23512 \\
\hline 4 & -15.08847 \\
\hline 5 & -14.04643 \\
\hline 6 & -13.20114 \\
\hline
\end{tabular}

Table 3. Johansen Co-integration Test

\begin{tabular}{lcccccc}
\hline $\begin{array}{l}\text { Hypothesized } \\
\text { No. of CE(s) }\end{array}$ & $\begin{array}{c}\text { Trace } \\
\text { Statistic }\end{array}$ & $\begin{array}{c}\text { Critical } \\
\text { Value }\end{array}$ & Prob. & $\begin{array}{c}\text { Max-Eigen } \\
\text { Statistic }\end{array}$ & $\begin{array}{c}\text { Critical } \\
\text { Value }\end{array}$ & Prob. \\
\hline None $*$ & 91.39658 & 69.81889 & 0.0004 & 51.08465 & 33.87687 & 0.0002 \\
\hline At most 1 & 40.31193 & 47.85613 & 0.2115 & 24.39167 & 27.58434 & 0.1216 \\
\hline At most 2 & 15.92026 & 29.79707 & 0.7179 & 10.31275 & 21.13162 & 0.7148 \\
\hline At most 3 & 5.607513 & 15.49471 & 0.7413 & 5.592141 & 14.26460 & 0.6659 \\
\hline At most 4 & 0.015372 & 3.841466 & 0.9012 & 0.015372 & 3.841466 & 0.9012 \\
\hline
\end{tabular}

Note: * significance level at 5percent.

Generally, the next step in the empirical study of long-run relations between variables is the VAR model application. However, based on our Johansen co-integration result, we found at least one co-integration as significant in the model. Thus, in such cases, the restricted form of the VAR model, which is the Vector Error Correction Model (VECM) is applied. The VECM model by applying an error correction term (ECT) can illustrate the long-run and short-run relationship between variables that are non-stationary in the level. The (ECT) term in the model shows the speed of correction to equilibrium from disequilibrium in the long term

Typical parameters applied in the analysis of the long-run and co-integration between predicted, and explanatory factors are as follow:

$$
\ln C P I=-0.314 \ln \left(R M_{t}\right)+0.142 \ln \left(M 2_{t}\right)-1.63 \ln \left(R E E R_{t}\right)-0.577 \ln \left(A E X_{t}\right)+5.067=0
$$

Or,

$$
\begin{array}{r}
\ln C P I=0.314 \ln \left(R M_{t}\right)-0.142 \ln \left(M 2_{t}\right)+1.63 \ln \left(R E E R_{t}\right)+0.577 \ln \left(A E X_{t}\right)-5.067 \\
(-9.16)
\end{array}
$$

Equation (4) represents the specification of the VECM results for a long term co-integration relationship between inflation (CPI) and other independent variables in the model. The values in parenthesis represent $t$ statistics. The finding indicates that all independent variables in the model have a significant positive impact on inflation in the 
long term. The positive impact of Independent variables $\ln M 2$, $\ln$ REER and $\ln A E X$ with inflation confirms a monetarist view for the reasons for inflation. The impact of the main variable of the study amount of remittance in the long term statistically positive with a 5 percent impact rate. The inflow of remittance results in the inflation rate in the case of Georgia, and it is 0.314 .

The findings of the model confirm the theory that the flow of remittance increases the demand of the receivers of remittances, which increases the demand and purchasing power of recipients, which puts pressure on prices and ultimately causes an increase in the overall price level. The findings confirm the studies of Bashir (2011), and Khan and Aslam (2013). If the results confirm the long-term relationship between variables, the VECM method is applied to analyze for the short-term relationship equation (5) represents the specification of the VECM results for the short term relationship between in (CPI) and other independent variables in the model.

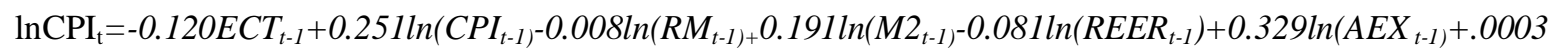

$$
\begin{array}{llllll}
(-2.71) \quad(2.37) \quad(-0.57) \quad(4.68) \quad(-0.85) \quad(3.23) \quad(0.11)
\end{array}
$$

The values in parenthesis are the t statistic values. The coefficients of the variables $\operatorname{lnCPI}, \ln \mathrm{M} 2$, and $\ln \mathrm{AEX}$ are significant and have an impact on inflation in the short-run; however, variables $\operatorname{lnRM}$ and $\operatorname{lnREER}$ are not significant and have no impact on the inflation rate in the short-run.

Based on short-run VECM analysis results, the error correction model coefficient is negative and important, suggesting that our model is stable, and inflation will return to its equilibrium at an annual rate of 12 percent. Inflation is positively impacted by the rise in remittances, and the increase in remittances has contributed to a statistically important long-term increase in inflation. In comparison, there were no major short-term ties between inflation and remittances in Georgia. The findings are based on the work of Narayan and Mishra (2011) that there is an important relationship in the long term between the amount of remittances obtained and the inflation rate in developing economies. The estimated diagnostic result provided in Table 4 indicates the robustness of the outcome prediction and there is no inconsistency here.

Table 4. Diagnostics test of the model

\begin{tabular}{lccccc}
\hline & \multicolumn{2}{c}{ Serial Correlation LM Tests } & \multicolumn{3}{c}{ Heteroskedasticity Tests } \\
\hline Lags & LM-Stat & Prob & Chi-sq & Df & Pob. \\
\hline 1 & 49.94 & 0.08 & 183.87 & 180 & 0.40 \\
\hline 2 & 32.03 & 0.15 & Sample: 2000Q1 2018Q4 & \\
\hline 3 & 23.05 & 0.57 & Included observations: 74 & \\
\hline
\end{tabular}

\section{Conclusion}

Remittances play a crucial role in developed countries as an alternative source of funding. Remittances substantially reduce poverty and foster economic development, but there is no scientific evidence to support the effect of remittances on inflation in Georgia. This paper estimates the short and long-term relationship between inflation rate, remittances, money supply, average real effective exchange rate and rate using quarterly data for 2000 to 2018 years, and analyzes the direct impact of remittance inflows on inflation in the long and short term. The findings show that the long-term and optimistic relationships of all the independent variables included in the analysis greatly explain the changes in inflation. ECT output shows a 12 percent adjustment rate of contingent variable inflation to balance.

The primary variable of the study remittance has a positive and significant impact on inflation in the long-run in Georgia. However, the study found no significant relationship between remittance inflow and inflation in the short-run. The paper indicates that the fact that remittance causes inflation is linked to the spending behavior of the recipients that raises the consumption, which puts pressure on prices in Georgia. In the event of Georgia, settlements of laborers, being the biggest wellspring of unfamiliar capital and a significant part of the equilibrium of installment, have an imperative function in boosting up the economy (Gerber and Torosyan, 2013; Charaia and Papava, 2017; Ito, 2019). The utilization example of the beneficiaries can be considered answerable for the inflationary part of the expansion. The examination proposes that settlement itself isn't wickedness, indeed it is the way where they got sum devoured which gets swelling the economy. So it tends to be inferred that the inflationary weight of the settlements in Georgia is because of the adjustments in the interesting side and the cash gracefully. Consequently, beneficial speculation is expected to counter the positive effect of the settlements on expansion.

Moreover, this study furthermore suggests that developing ways on how to transfer remittances to investment projects rather than on consumption. In order to ensure that these money flows remain beneficial to the recipient economy, policies should be placed in place to direct the use of remittances. Empirical evidence shows that 
remittances must be channeled into economic domains that are productive. The biggest problem for the Georgian economy is the movement of remittances into the realms of profit-making and education.

Remittance also affects Georgia's exchange rate; international remittances are important for maintaining Georgia's exchange rate stability. The study suggests an overview of the remittance-to-investment process.

\section{References}

Acosta, P., Calderón, C., Fajnzylber, P., \& Lopez, H. (2008). What is the Impact of International Remittances on Poverty and Inequality in Latin America?. World Development, 36(1), 89-114.

Adelman, I., \& Taylor, J. E. (1990). Is structural adjustment with a human face possible? The case of Mexico. The Journal of Development Studies, 26(3), 387-407.

Agenda.ge. (2020). Retrieved October 27, 2020, from https://agenda.ge/en/news/2020/802

Balderas, J. U., \& Hiranya, K. N. (2005). Remittances, Relative Price Variability and Inflation in Mexico. Paper presented at the 75th annual meeting of the Southern Economist Association, Washington, DC.

Ball, C. P., Lopez, C., \& Reyes, J. (2013). Remittances, Inflation and Exchange Rate Regimes in Small Open Economies 1. The World Economy, 36(4), 487-507.

Bourdet, Y., \& Falck, H. (2006). Emigrants' remittances and Dutch disease in Cape Verde. International Economic Journal, 20(3), 267-284.

Caceres, L. R., \& Saca, N. N. (2006). What do remittances do? Analyzing the private remittance transmission mechanism in El Salvador (No. 6-250). International Monetary Fund.

Charaia, V., \& Papava, V. (2017). The role of inflation and its targeting for low-income countries (Lessons from post-communist Georgia). European Journal of Economic Studies, 6(2), 96-103.

Dickey, D. A., \& Fuller, W. A. (1981). Likelihood ratio statistics for autoregressive time series with a unit root. Econometrica: Journal of the Econometric Society, 49(4), 1057-1072.

Faisal, A., Amjad, M., \& Arifa, S. (2017). What determine remittances to Pakistan? The role of macroeconomic, political and financial factors. Journal of Policy Modeling, 39(3), 519-531. https://doi.org/10.1016/j.jpolmod.2017.03.006

Gerber, T. P., \& Torosyan, K. (2013). Remittances in the Republic of Georgia: Correlates, economic impact, and social capital formation. Demography, 50(4), 1279-1301.

Glytsos, N., \& Katseli, L. T. (1986). Theoretical and empirical determinants of international labour mobility: A Greek-German perspective (No. 148). CEPR Discussion Papers.

Gupta, S., Pattillo, C. A., \& Wagh, S. (2009). Effect of Remittances on Poverty and Financial Development in Sub-Sahara Africa. World Development, 37(1), 104-115.

Imai, K. S., Gaiha, R., Ali, A., \& Kaicker, N. (2014). Remittances, growth and poverty: New evidence from Asian countries. Journal of Policy Modeling, 36(3), 524-538.

Iqbal, J., Nosheen, M., \& Javed, A. (2013). The Nexus between Foreign Remittances and Inflation: Evidence from Pakistan. Pakistan Journal of Social Sciences, 33(2), 331-342.

Ito, K. (2019). Remittances and the Dutch disease: evidence from Georgia. Post-Communist Economies, 31(4), 500-506.

Johanna, E., Charlotte, S., \& Farid, M. (2017). Do remittances respond to revolutions? The Evidence from Tunisia. Research in International Business and Finance, 94-101. https://doi.org/10.1016/j.ribaf.2017.04.044

Johansen, S. (1988). Statistical analysis of cointegration vectors. Journal of Economic Dynamics and Control, 12(2-3), 231-254.

Johansen, S., \& Juselius, K. (1990).Maximum likelihood estimation and inference on Cointegration-with applications to the demand for money. Oxford Bulletin of Economics and Statistics, 52(2), 169-210.

Keynes, J. M. (1929). The German transfer problem. The Economic Journal, 39(153), 1-7.

Khan, Z. S., \& Islam, S. (2013). The Effects of Remittances on Inflation: Evidence from Bangladesh. Journal of Economics and Business Research, 2, 198-208.

Lartey, E. K., Mandelman, F. S., \& Acosta, P. A. (2012). Remittances, exchange rate regimes and the Dutch disease: A panel data analysis. Review of International Economics, 20(2), 377-395. 
Lopez, H., Bussolo, M., \& Molina, L. (2007). Remittances and the real exchange rate. World Bank Policy Research Working Paper, (4213).

Merima, B. (2011) The Role of Remittences in the Explanation of Feldstein-Horioka Paradox: Evidence from Transition Economies. Economic Research-Ekonomska Istraživanja, $24(4), \quad 91106$. https://doi.org/10.1080/1331677X.2011.11517483

Mughal, M. Y. (2012). Remittances as Development Strategy: Stepping Stones or Slippery Slope?. Journal of International Development, 25(4), 583-595.

Mumuni, A., \& Quaidoo, C. (2016). Effect of International Remittances on Inflation in Ghana Using the Bounds Testing Approach. Business and Economic Research, 6(1), 192-209.

Narayan, P. K., Narayam, S., \& Mishra, S. (2011, April). Do remittances induce inflation? Fresh evidence from developing countries. Southern Economic Journal, 77(4), 914-933.

Narayan, P., Narayan, S., \& Mishra, S. (2011). Do remittances induce inflation? Fresh evidence from developing countries. Southern Economic Journal, 77(4), 914-933.

Nath, H. K., \& Vargas-Silva, C. (2012). Remittances and relative prices. Review of Development Economics, 16(1), 45-61.

National Bank of Georgia Report (2018). Retrieved January 18, 2019, from https://www.nbg.gov.ge/index.php?m=304

Nisar, A., \& Tufail, S. (2013). An Analysis of Relationship between Remittances and Inflation in Pakistan. Zagreb International Review of Economics \& Business, 16(2), 19-38.

Nyamongo, E. M., Misati, R. N., Kipyegon, L., \& Ndirangu, L. (2012). Remittances, financial development and economic growth in Africa. Journal of Economic and Business, 64(3), 240-260.

Ohlin, B. (1929). The reparation problem: a discussion. Economic Journal. Retrieved from http://www.hifreqecon.com/nyu/ohlin29.pdf

Puja, G. (2013). Macroeconomic effects of international remittances: The case of developing economies. Economic Modelling, 33, 292-305. https://doi.org/10.1016/j.econmod.2013.04.016

Rao, B., \& Hassan, G. (2011). A panel data analysis of the growth effects of remittances. Economic Modelling, 28(1-2), 701-709.

Rashid, A., \& Husain, F. (2013). Capital inflows, inflation, and the exchange rate volatility: an investigation for linear and nonlinear causal linkages. The Pakistan Development Review, 183-206.

Rivera, J. P. R., \& Tullao Jr, T. S. (2020). Investigating the link between remittances and inflation: evidence from the Philippines. South East Asia Research, 1-26.

Roy, R., \& Rahman, M. M. (2014). An empirical analysis of remittance -inflation relationship in Bangladesh: post-floating exchange rate. Retrieved from http://mpra.ub.uni-muenchen.de/55190.pdf

Tiwari, A. K., \& Mutascu, M. (2011). Economic growth and FDI in Asia: A panel-data approach. Economic Analysis and Policy, 41(2), 173-187.

Tung, L. T., Ly, P. T. M., Nhu, P. T. Q., Thanh, P. T., Anh, L. T., \& Phung, T. T. P. (2015). The impact of remittance inflows on inflation: evidence in Asian and the Pacific developing countries. Journal of Applied Economic Sciences, 10(7), 37.

Uzagalieva, A., \& Menezes, A. (2009). The poverty effect of remittance flows: evidence from Georgia. Post-communist Economies, 21(4), 453-474.

World Bank Report on Remittance (2018). Retrieved March, 22, 2019, from http://documents.worldbank.org/curated/en/805161524552566695/pdf/125632-WP-PUBLIC-MigrationandDev elopmentBrief.pdf

\section{Copyrights}

Copyright for this article is retained by the author(s), with first publication rights granted to the journal.

This is an open-access article distributed under the terms and conditions of the Creative Commons Attribution license (http://creativecommons.org/licenses/by/4.0/). 